\title{
CONTROL SYSTEM PREVENTING THERMAL GRADIENT DEVELOPMENT ON FOILS OF FOIL BEARING
}

\begin{abstract}
This article presents attempts at automating a control system to reduce temperature scatter on the foil of a foil bearing. The control system reads the temperatures at six circumferential locations of the bearing's foil and distributes control currents to the thermoelectric modules integrated into the bearing's bushing. Three basic approaches have been proposed and tested: 1) a simple hot-spot tracking algorithm assigning predefined current values to the modules closest to the hot-spot location; 2) a tracking algorithm reducing abrupt changes in the control currents and, in effect, the local heat flux distribution; and 3) a tracking algorithm enhanced with a PID controller. The proposed controller has been implemented and compared to the performance of a temperature controller that does not have tracking capabilities. The implemented control strategies have proven the feasibility of temperature scatter reduction inside the investigated bearing. In most test cases, the instantaneous gradient reduction exceeded 50\% (reaching 63\% at its best).
\end{abstract}

Keywords: thermoelectric temperature control, foil bearings, adaptive control

\section{SYSTEM PRZECIWDZIALAJACY POWSTAWANIU NADMIERNEGO GRADIENTU TERMPERATURY $W$ ŁOŻYSKACH FOLIOWYCH}

Artykut opisuje podjęte przez autorów próby automatyzacji systemu regulacji przeciwdziałającego powstawaniu wysokiego gradientu temperatury $w$ łożyskach foliowych $w$ warunkach zmiennego obciązenia tych łożysk. Zbudowany system bazuje na sześciopunktowym pomiarze temperatury $w$ równoodległych pozycjach na obwodzie łożyska, na podstawie których określa wartości prąów zasilających zabudowane w panwi łożyska moduly termoelektryczne. W pracy opisano wyniki eksperymentów uzyskane dla trzech różnych sposobów wyznaczania prąów sterujacych: 1) orientację z góry ustalonego rozkładu prądów określa prosty algorytm śledzący pozycje wystąienia maksymalnej temperatury na obwodzie łożyska; 2) algorytm śledzący jw. z rozkładem prądów zmodyfikowanym tak, aby zmiana pozycji obwodowej środka tego rozkładu nie powodowała skokowych zmian w prądach sterujących poszczególnych modułów; 3) algorytm śledzacy jw. z dołaczonym regulatorem PID. Efekty regulacji z wykorzystaniem zaimplementowanego regulatora porównano do prostego układu regulacji, który nie śledzi zmian kierunku wystąienia temperatury maksymalnej na obwodzie tożyska. W artykule wykazano skuteczność opracowanego rozwiąania, które $w$ większości zbadanych przypadków testowych prowadziło do redukcji gradientu o min. 50\% (najlepszy uzyskany wynik to 63\%).

Stowa kluczowe: termoelektryczne systemy regulacji temperatury, łożyska foliowe, adaptacyjne systemy sterowania

\section{INTRODUCTION}

Gas foil bearings (GFB) have recently started to be used in high-speed and lightly loaded turbomachinery. Despite their numerous advantages, GFBs suffer from uneven thermal growth in the composing elements and developing thermal gradients. The latter is most dangerous, as it leads to usually unexpected bearing's failure (Dykas, Howard 2008).

The heat conduction in a bearing is limited to the radial direction due to the small contact area between the top foil, bump foil, and bushing. Overheating in the foils may lead to bearing failure - the higher the temperature, the lower the load capacity and stiffness of a bearing (San Andrés et al. 2011). As most of the generated heat is transferred to the shaft, the temperature expansion rate of bearing compo- nents differ significantly, which can eventually lead to seizure (Ryu, San Andrés 2013). Local disturbances in heat flux distribution may cause temperature gradients to develop. Axial and radial temperature gradients can make a foil wrap on its edges; as a result, even a small gradient may restrict air flow between the foils. When air leakages are restrained, bearing temperatures rise. Bearing elements continue to expand, making this process self-perpetuating. At a critical point, clearance is reduced to zero and may cause the shaft to weld to the foil, which is the equivalent of bearing failure (Radil, Batcho 2010).

Thermal gradients are especially dangerous because they may lead a stable GFB to failure in the cases of rapid load or speed changes. This problem is a threat to thin-walled bearings or highly loaded bearings when exposed to shock loads.

* AGH University of Science and Technology, Faculty of Mechanical Engineering and Robotics Department of Robotics and Mechatronics, Krakow, Poland; e-mail: michal.lubieniecki@agh.edu.pl 
A standard approach to the thermal management of GFB is forcing air to flow either through the hollow shaft or foil bumps (Radil et al. 2008). The use of thermoelectric modules (TEM) was firstly proposed in (Roemer et al. 2015) and further investigated in (Lubieniecki et al. 2016). The performed experiments proved that TEMs could be effectively used to reduce a circumferential thermal gradient from developing in GFBs.

The initially adopted approach required numerical simulations to be performed in order to assign control currents to the individual TEM. Although this approach proved to be successful, its practicality may be easily questioned. This paper presents a step towards the control process automation that allows us to skip power- and time-consuming numerical simulations in the previously-used model-based approach. In the proposed control scheme, the TEMs' currents are determined by a closed-loop controller to keep the circumferential gradient as low as possible (and also when a bearing's load distribution changes).

\section{THE PROBLEM STATEMENT}

In this paper, TEMs (RMT 1MDL06-024-15) are used to make the temperature distribution (scatter) on a bearing's foil uniform by inducing local heat flows rather than lowering the global bearing's temperature. An array of nine TEMs (on the circumference) per four (along the axis) were integrated in the bearing bushing to provide flexibility and high spatial resolution in the hot-spot re- moval. The TEMs and foils are separated by a 2 -mm-thick ring to provide the necessary support for the foils and limit operational mechanical stress (tensile and shear) on the modules. The thermocouples are spaced around the bushing; there are 21 points where thermocouples may be installed. The inspection holes are spaced evenly (every $120^{\circ}$ ) at each position, providing access to the top (three points along the axis) and bump foil (four points along the axis). The number of actually-used sensors was determined in the course of the experiments. A detailed description of the addressed bearing construction can be found in (Lubieniecki et al. 2016). The overall view of the experimental setup is shown in Figure 1. The bearing assembly with an electric spindle (A) is placed on a heavy support. However, in the course of the experiment, the spindle was used as a support only; the experiments were conducted on the still bearing. The NI sinking outputs modules (B) act like low-side switches controlling the current flowing to the TEMs from the switching power supply (C). The main control loop is executed on the NI PXI platform (invisible on the picture), and the operator can monitor the whole process through the LabView environment (D). A more-detailed description of the hardware used $(\mathrm{B}, \mathrm{C}, \mathrm{D})$ is provided in the next chapter.

Although the prototype system was implemented in a general-purpose platform intended for the fast prototyping of the control systems, the main consideration was to propose a control scheme that is simple, reliable, and easy to implement in a universal industrial controller.

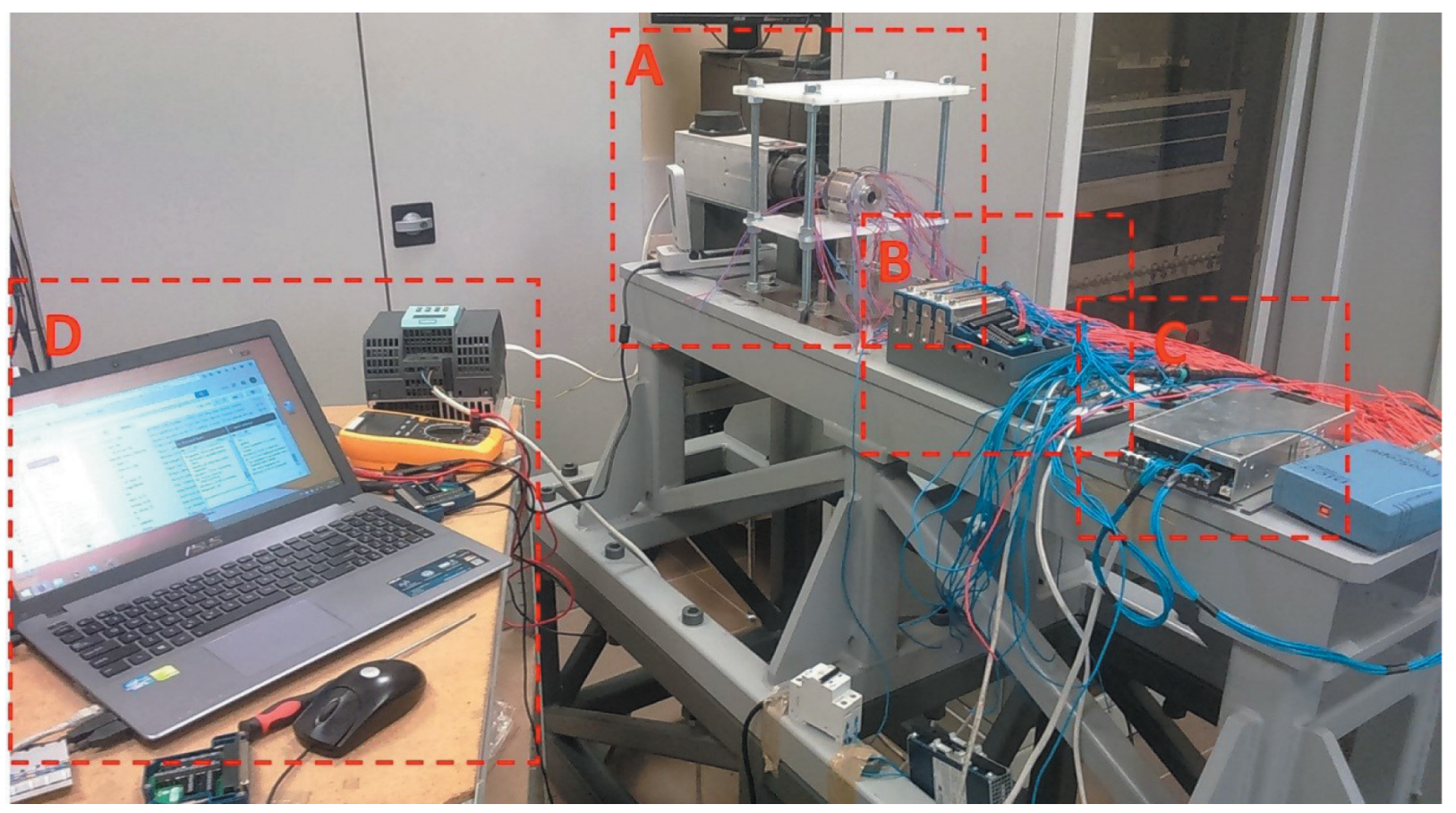

Fig. 1. Overall view of experimental setup: A - bearing assembly mounted on support; $\mathrm{B}$ - sinking I/O delivering control currents to TEMs; C - power supply; D - operator interface (accessible through LabView environment) 
Three basic approaches have been proposed and tested: a simple hot-spot tracking algorithm (assigning pre-defined current values to the modules closest to the hot-spot location); a tracking algorithm (reducing abrupt changes in the control currents and, in effect, the local heat flux distribution); and a tracking algorithm (enhanced with a PID controller).

\section{CONTROL SYSTEM IMPLEMENTATION}

The control system has been implemented within a general-purpose National Instruments measurement and automation platform based on a rugged PC with a modular expansion case (Fig. 2). The programmable digital outputs, with a capability of sinking up to $1.2 \mathrm{~A}$ per channel (up to $2 \mathrm{~A}$ when all channels are not in use), control the individual currents of the interconnected TEMs.

The host computer acts only as a user interface and data logger. The operator can trigger the execution of the control scheme but cannot modify the controller parameters while it is in operation. A high-level description of the implemented control scheme is presented as a block diagram in Figure 3.

The main program has been divided into three parts, executed in parallel. One sub-routine transmits data between the host computer and remote system (left branch in the diagram). The other sub-routine is responsible for conditioning the signals provided by the thermocouples (right branch in the diagram). In the main loop, control currents for the individual TEM are calculated and then sent to the FPGA-based controller. It is the main loop where the tracking algorithm is sealed and (optionally) the PID controller is implemented. The control-current distribution can also be set manually. The TEMs can be arbitrarily grouped together so that each TEM in a group receives the same control signal.

As found during the initial trials, the resultant temperature distribution inside a bearing depends not only on the current, but also on the prior values of the control currents. This observation was made for a steady heat influx (i.e., stable operating conditions). Hence, without performing the numerical simulations or using the tracking algorithm, it is impossible to predict the cooling effects when the current setup is arbitrarily changed.

To adapt to the changing temperature distribution in a bearing, a simple algorithm for tracking the maximum temperature's location was implemented (Fig. 4). In the case of the tracking circumferential gradient only, the thermocouple readings are grouped and averaged along the bearing axis. The known position of the thermocouples unambiguously describes the hot-spot location. Due to the unreliable measurement (contact issues) on the top foil, only the bump foil measurements were used in this research.

The PID controller sets the currents prescribed to the modules closest to the hot-spot based on the measured temperature scatter (maximum difference noticed). The controller parameters were fine-tuned by trial and error.

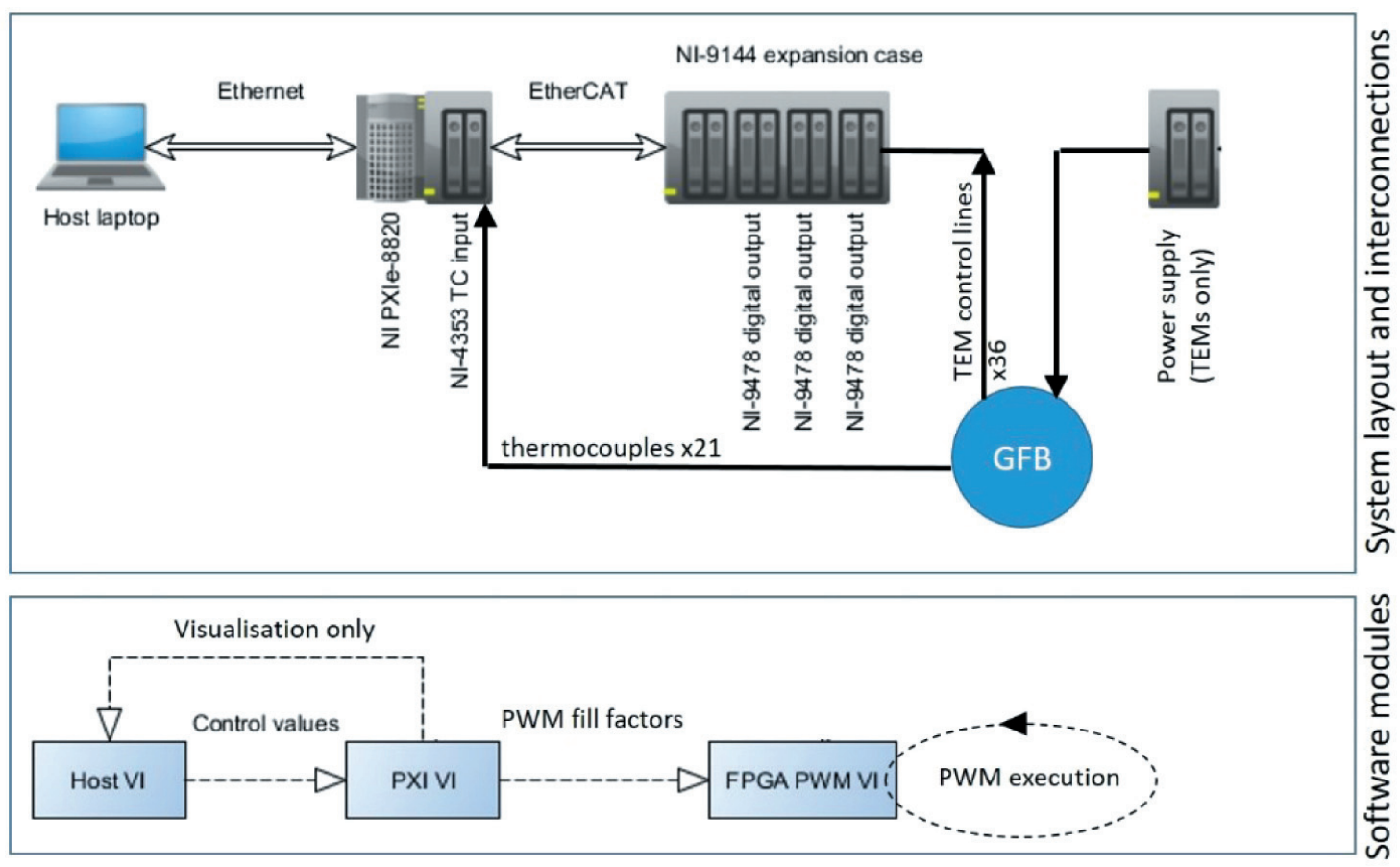

Fig. 2. Scheme of control system with interconnections between its functional elements. Software modules executed on each platform are shown in underlying scheme 


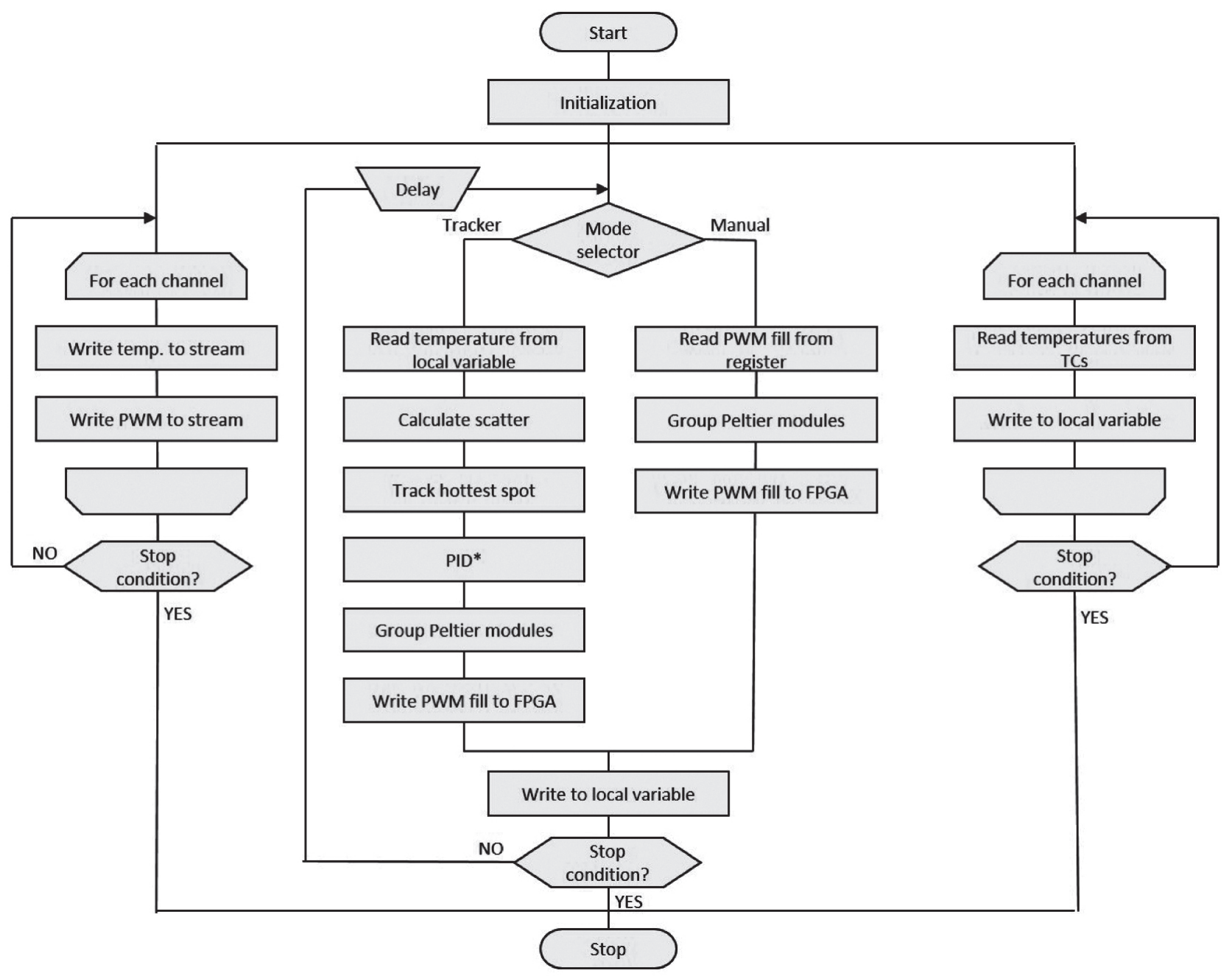

Fig. 3. Main control loop executed on remote platform (NI PXI)

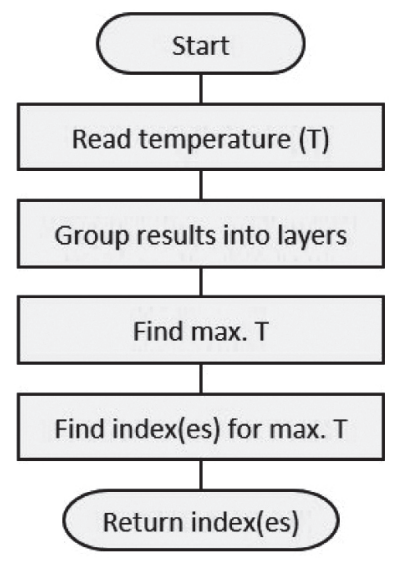

Fig. 4. Tested hot-spot tracking algorithm

\section{EXPERIMENTAL VERIFICATION}

During the experiments, attempts to reduce only the circumferential gradient were undertaken; hence, the four Peltier modules at the same circumferential position were grouped from the software interface, and controlled with the same PWM fill factor. To limit the loss of efficiency due to current ripples, the proper PWM frequency must be used.
At the same time the PWM frequency should be kept possibly high to minimize thermal expansion stresses and repetitive temperature changes, as they can lead to fatigue and significantly increase the risk of module failure. When operated appropriately, the TEM's MTBF of $100,000-300,000 \mathrm{~h}$ is achievable. It was experimentally determined that, for the purpose of the application, the frequency of $1 \mathrm{kHz}$ is enough to satisfy all of the demands mentioned above.

The maximum PWM fill factor used was $37 \%$, which corresponds to a current value of $1 \mathrm{~A}$. Higher PWM fill factors led to a deterioration in the achieved results due to excessive Joule's heat generation. The adopted TEM's and the thermocouple names are shown in Figure 5. As the axial gradient in considered loadcase is insignificant, the number of inputs to the control system was reduced to only six (temperature readings at the same circumferential position were averaged). A cartridge heater was used to invoke the uneven temperature distribution inside a bearing by choosing one of the eccentrically disposed slots (I-V: slot V was used during the tests). The heat supplied to the bearing was at a level of $1 \mathrm{~W}$ for each performed test. 

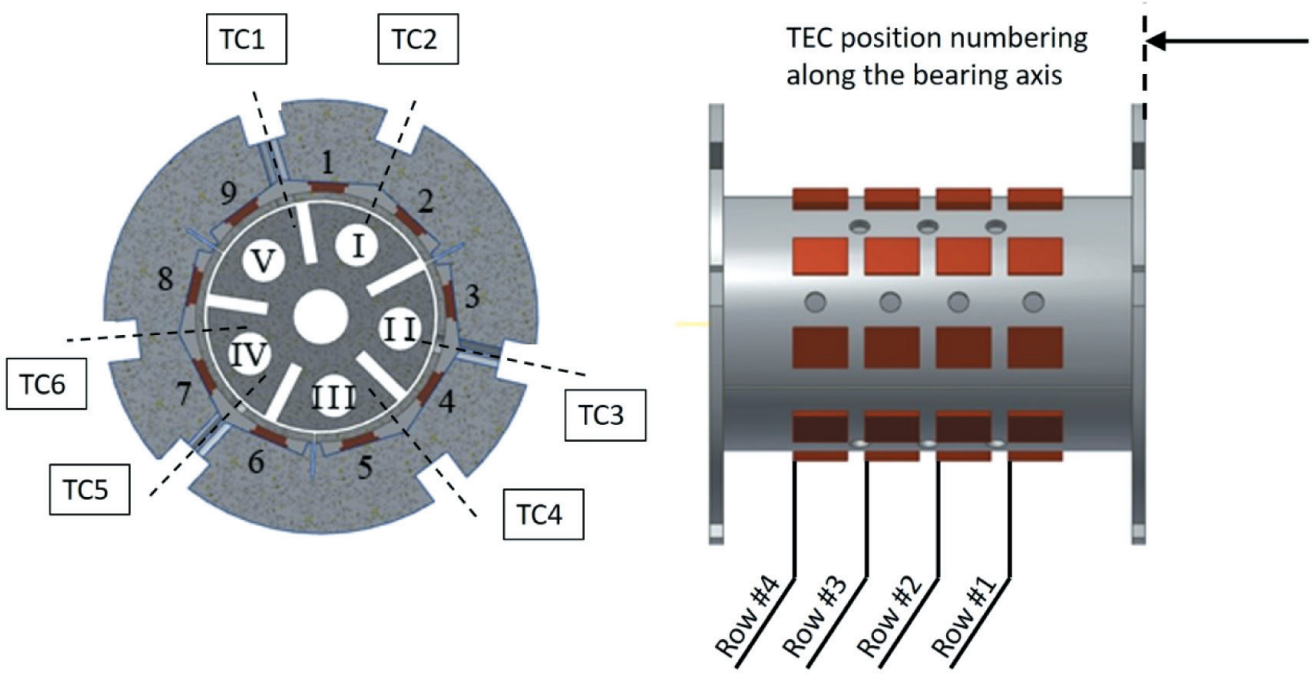

Fig. 5. Foil bearing assembly with adopted naming convention for thermocouples, TEM, and heater slots. Actual position of shaft inside bearing during tests might be slightly different than shown

Three distinct test configurations were used; i.e., manual setting of PWM fill factor, automatic tracking of hot-spot location with constant PWM fill factor, and automatic tracking of hot-spot location with PWM fill adjusted by the PID controller.

\section{First test configuration}

The first test assumed a PWM fill set manually to $37 \%$ and $30 \%$ on Rows 1 and 9 (a total of 8 modules were activated). The maximum scatter reduction acquired during the test was $55 \%$, from an initial $0.56^{\circ} \mathrm{C}$ to $0.25^{\circ} \mathrm{C}$ (Fig. 6). However, the cooling effect turned out to be unstable. Both the gradient and temperatures rose continuously during the test.

a)

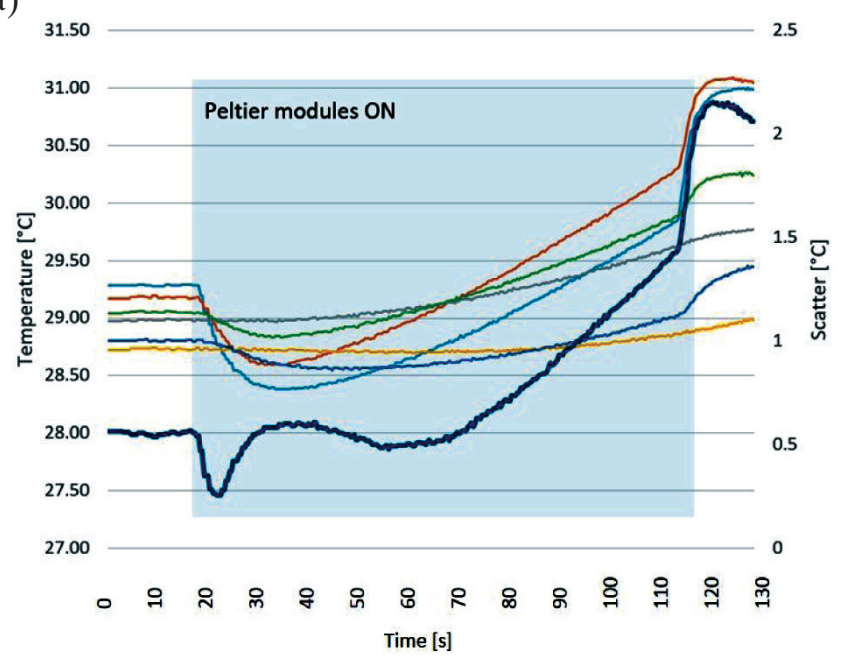

It can be observed that the thermocouples furthest from the heater (locations T3-T5) were the least influenced. As the outer bearing bushing is divided into three thermally insulated components (and due to the slow heat removal rate at the outer surface of the bearing), the control effect was unsteady. The heat expelled on the hot side of the active modules could be conducted through inactive modules 2, 3, 7, and 8 heating up the foils. Similar behavior was not observed when more modules were activated at the same time (Lubieniecki et al. 2016).

The steady-state value of the temperature scatter value was not achieved. After turning off the modules, the regeneration phase can be clearly identified at which temperatures temporarily rise above the initially observed value.

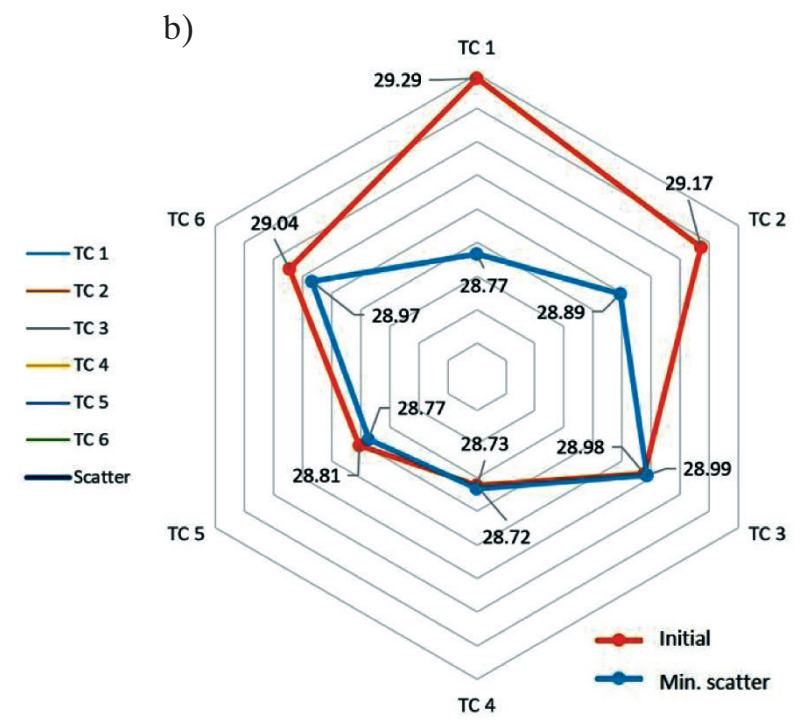

Fig. 6. The results obtained for the first investigated configuration: a) time plots of temperatures and scatter recorded during test (no tracking); b) geometrical temperature distribution on bearing circumference.

Initial temperature values (orange) are compared to values for maximum achievable scatter reduction (blue) 


\section{Second test configuration}

During the performed test, the tracking algorithm that follows the changes in temperature distribution was used to provide currents only for the TEMs closest to the host-spot location. During this test, the maximum PWM fill was set to $30 \%$, which corresponds to a current value of $0.8 \mathrm{~A}$.

A gradient reduction of $63 \%$ was observed (from an initial $0.56{ }^{\circ} \mathrm{C}$ to $0.21{ }^{\circ} \mathrm{C}$ - see Fig. 7). The temperature scatter seems to be stable over time; however, its fluctuations are noticeable. The overall temperature rise of the bearing is observable (as previously reported in the first test configuration).

\section{Third test configuration}

In the third performed test, the PWM fill was controlled within a range of 0 to $37 \%$ by a single PID controller assigning the currents to the TEM closest to the hot-spot locations. Regulator gains were chosen by trial and error. The test was performed with the regulator parameters set as follows: $K_{p}=400 ; K_{d}=0.05$. The achieved gradient reduction was $53 \%$ (from an initial $1.08{ }^{\circ} \mathrm{C}$ to $0.51{ }^{\circ} \mathrm{C}$ - see Fig. 8).

The cooling effect can be observed instantly, and the temperature rise during the regeneration phase is not as high as previously noted due to the PID controller (Fig. 8). Compared to the second test configuration, the observed scatter fluctuations are less prominent. The difference is especially visible in the fluctuation frequency. Additional measurement were taken with the TEMs being switched repeatedly from active to inactive to assess the cooling effect repeatability. The instantaneous effect is comparable in terms of scatter reduction, although an overall rise in temperature is visible. The control signals (PWM fill factors) for individual modules can be seen in Figure 9b. a)

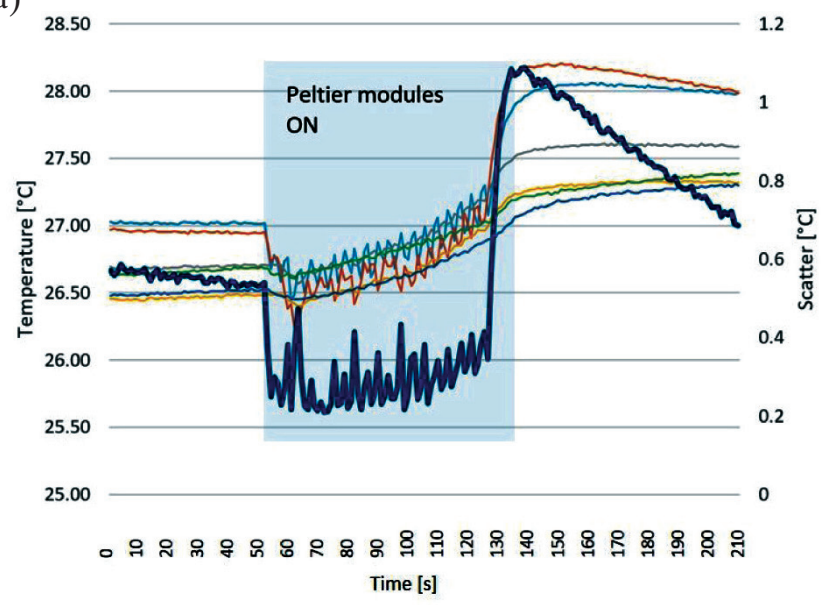

b)

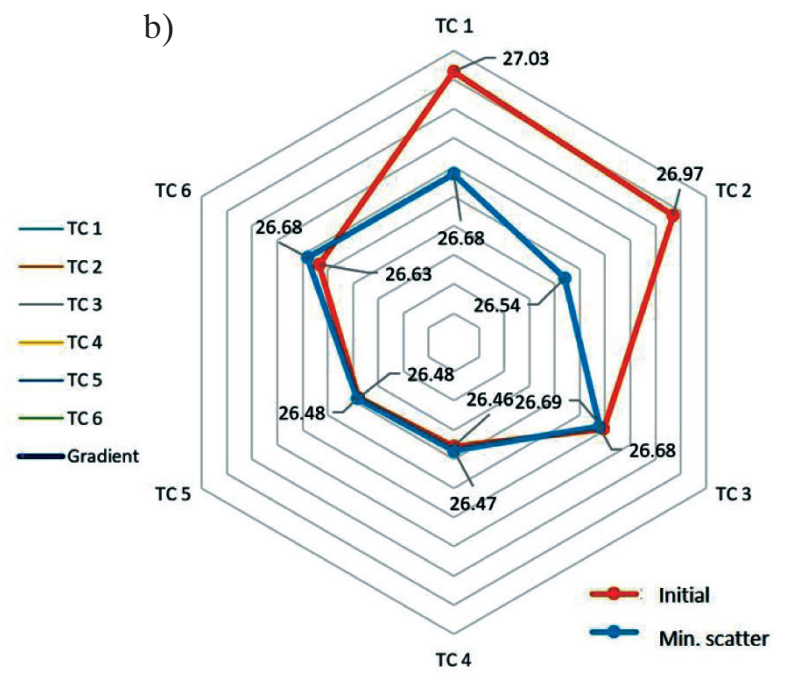

Fig. 7. The results obtained for the second investigated configuration: a) time plots of temperatures and scatter recorded during test (with tracking algorithm); b) geometrical temperature distribution on bearing circumference. Initial temperature values (orange) are compared to values for maximum achievable scatter reduction (blue)
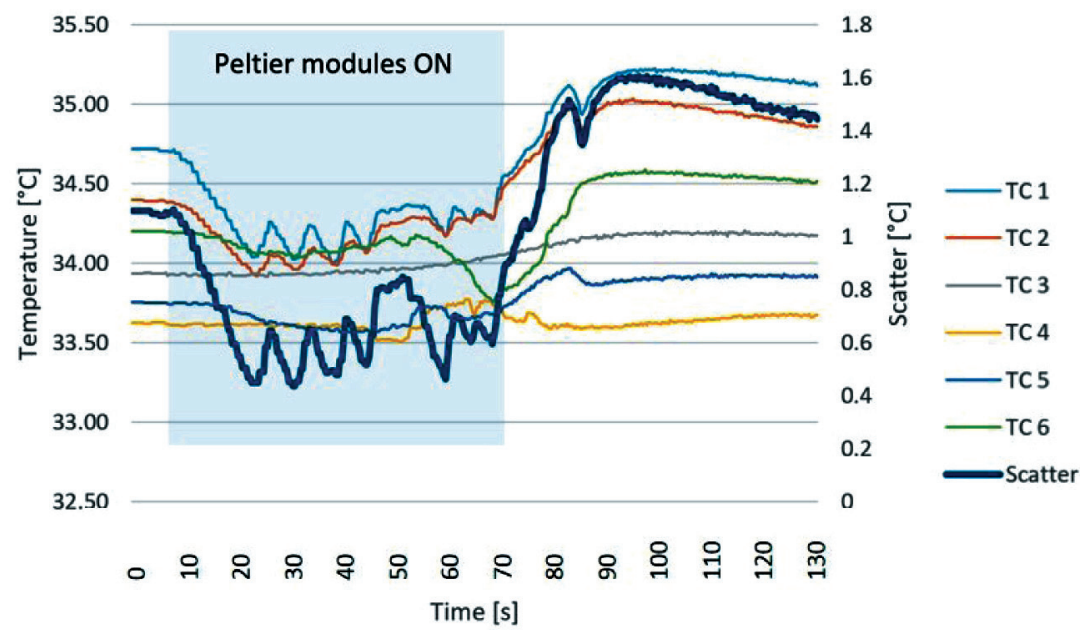

Fig. 8. Time plots of temperatures and scatter recorded during test (with tracking algorithm and PID controller) 
a)

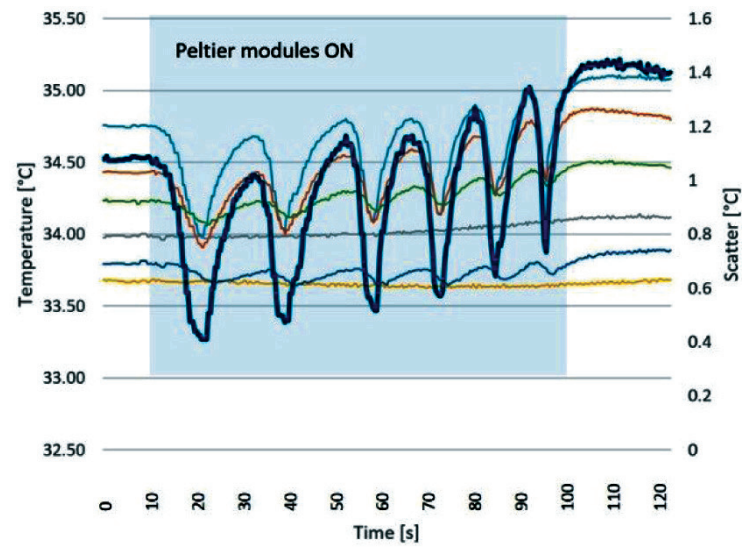

b)

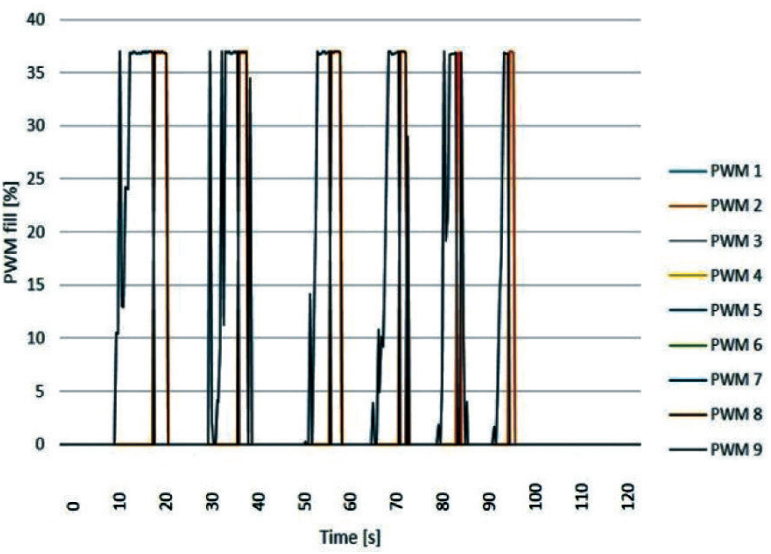

Fig. 9. The results obtained for the third investigated configuration: a) time plots of temperatures and scatter recorded during test (with tracking algorithm and PID controller); b) corresponding PWM fill values [\%]

prescribed to modules grouped in Rows 1-9

Even though the cartridge heater remained in the same slot, it is clearly visible that the hottest point changed locations many times within the observation period.

\section{SUMMARY}

The implemented control strategies have proven feasible in terms of the temperature scatter reduction inside an investigated bearing. In most test cases, the instantaneous gradient reduction exceeded $50 \%$, and the best-achieved reduction was $63 \%$.

The test conditions might be considered disadvantageous, as the heat removal rate from the bushing was very slow; this is also due to the fact that a steady bearing does not remove heat through the air leakages. This was identified as the reason for the unstable scatter obtained in the first test configuration. The overall temperature of the bearing assembly rose during the tests; this trend, however, was not considered detrimental to the bearing's thermal stability, especially when accompanied by a reduction in temperature scatter.

The proposed automated control system might be easily transferred to standard industrial hardware due to its simplicity. The automatic hot-spot tracking system worked efficiently, providing stable scatter reduction. Different groups of modules were launched repeatedly, even though the cartridge heater did not change its location. In effect, the control algorithm dealt efficiently with the local heat flux disturbances caused by the working TEMs.
Future research will cover testing the bearing under normal operating conditions, when naturally developing thermal gradients appear.

\section{ACKNOWLEDGMENTS}

The authors acknowledge the project "The use of thermoelectric materials to improve thermal stability of high-speed rotor bearings systems,” no. PBS1/A6/6/2012 financed by the National Center for Research and Development.

\section{References}

Dykas B., Howard S.A., 2008, Journal design considerations for turbomachine shafts supported on foil air bearings. Tribology Transactions 47(4), 508-516.

Lubieniecki M., Roemer J., Martowicz A., Wojciechowski K., Uhl T., 2016, A multi-point measurement method for thermal characterization of foil bearings using customized thermocouples. Journal of Electronic Materials 45(3), 1473-1477.

Radil K., Batcho C.D.T.Z., 2010, A novel thermal management approach for radial foil air bearings, (July). Army Research Laboratory NASA Glenn, Cleveland, ARL-MR-0749.

Radil K., Dellacorte C., Zeszotek M., 2008, Thermal management techniques for oil-free turbomachinery systems. Tribology Transactions 50(3), 319-327.

Roemer J., Lubieniecki M., Martowicz A., Uhl T., 2015, Multi-point control method for reduction of thermal gradients in foil bearings based on the application of smart materials. 7th ECCOMAS Thematic Conference on Smart Structures and Materials SMART 2015, Ponta Delgada, Azores, Portugal.

Ryu K., San Andrés L., 2013, On the failure of a gas foil bearing: high temperature operation without cooling flow. Journal of Engineering for Gas Turbines and Power 135(11), 112506.

San Andrés L., Ryu K., Kim T.H., 2011, Identification of structural stiffness and energy dissipation parameters in a second generation foil bearing: Effect of shaft temperature. Journal of Engineering for Gas Turbines and Power 133(March), 032501. 